Makale türü / Article type: Araştırma / Research

\title{
Latife Tekin'in Manves City Romanına Yansıyan Türkiye
}

$* * *$

\section{Turkey Reflected on Latife Tekin's Novel Named Manves City}

\author{
Dr. Öğr. Üyesi Semih ZEKA \\ Dr. Öğr. Üyesi, Erciyes Üniversitesi, Eğitim Fakültesi, zekasemih@ hotmail.com \\ ORCID: 0000-0003-2319-5229
}

\begin{abstract}
Özet
1983 yılında yayımlanan Sevgili Arsız Ölüm adlı ilk romanıyla adını duyuran Latife Tekin, daha sonraki yıllarda kaleme aldı̆̆ romanlarıyla Türk edebiyatında önemli bir yere sahip olur. 2018 yılında Latife Tekin'in Sürüklenme ve Manves City adlarındaki iki romanı birlikte yayımlanır. Toplumun her kesiminden ama özellikle yoksul kesimden insanların ele alındığı Manves City'de yazar, Erice kasabası bağlamında değişmekte olan Türkiye'nin birey ve toplum üzerindeki etkilerini ele alır. Bu çalı̧̧mada Latife Tekin'in perspektifinden Türkiye'nin yansıdığı Manves City adlı romanın, aile, çalışma hayatı, yitirilen değerler, göç, kadın, şehirleşme ve tabiatın tahribi bağlamında incelenmesi amaçlanmıştır.
\end{abstract}

Anahtar Kelimeler: Latife Tekin, Manves City, Roman, Türk Edebiyatı

Jel Sinıflandırması: Y30, Y92

\begin{abstract}
Latife Tekin who made a name for herself with her first novel named Sevgili Arsiz Ölüm which was published in 1983 has an important place in Turkish literature with her novels she wrote in later years. Latife Tekin's two novels, Sürüklenme and Manves City were published in 2018. In Manves City which people from all sections of the society, but especially from the poor, are handled, the writer examines the effects of changing Turkey on the individual and the society. In this study, the examining of the novel named Manves City reflecting some aspects of Turkey from the perspective of Latife Tekin is aimed in the context of family, working life, loss of moral values, immigration, women, urbanization and the destruction of nature.
\end{abstract}

Key Words: Latife Tekin, Manves City, Novel, Turkish Literature

Jel Classification: Y30, Y92

\section{GíRiş}

Latife Tekin, 1980 sonrası Türk romanının önemli isimlerinden biridir. 1983 yılında yayımlanan ilk romanı Sevgili Arsız Ölüm'de köyden şehre göçün etkilerini kendi hayat tecrübelerini de katarak dile getirirken yine çocukluk döneminde anne ve babasından dinlediği, kitaplardan okuduğu masalların havasını da yansıtır. Senaryo, deneme ve anı türlerinde de eserler veren Latife Tekin'in Sevgili Arsız Ölüm dışında Berci Kristin Masalları, Gece Dersleri, Buzdan Kılıçlar, Aşk Işsaretleri, Ormanda Ölüm Yokmuş, Unutma Bahçesi, Muinar adında romanları da vardır. Büyük bir şehirde ayakta kalma mücadelesi veren bir ailenin bireyi olan Latife Tekin'in özellikle ilk dönem romanlarının merkezinde yoksulluk yer alır (Balık, 2011: 23-25).

Latife Tekin'in romanlarında köyden şehre göç eden insanların hayat şekillerine paralel olarak kullandıkları kelimelerin de değişmesi sezilir. Mizah ve hüznün bir arada bulunduğu kimi romanlarında yoksulluk ise başat unsurlardandır. $\mathrm{O}$, yoksul mahallelerde hayata tutunmaya çalışan insanın kendini ve dünyayı algılayışındaki değişimi de yansıtır (Atik, 2011: 25). Bununla birlikte “(...) romanlarının gittikçe çevreci eleştiri çizgisine yaklaştığı, eko-sosyalist ve eko-feminist bakış açısının onun romanlarını besleyen 
kaynaklar olduğu görülür" (Balık, 2011: 32). Bu çalışmada Latife Tekin'in 2018 y1lında Sürüklenme ile birlikte yayımlanan Manves City adlı romanına aile, çalışma hayatı, yitirilen değerler, göç, kadın, şehirleşme ve tabiatın tahribi bağlamında Türkiye'nin yansıyışı incelenmiştir.

\section{TÜRKIYE'DE AILLE KURUMUNUN MANVES CITY'E YANSIYAN HALİ}

Latife Tekin, Manves City'de aile kurumuna öncelikle aileyi oluşturan bireyler arasındaki iletişim eksikliği ve bunun bireylerin hayatına olumsuz etkileri bağlamında yer verir. Romanda bireyler arasında sorunların dinlenip tartışıldığı bir aile ortamı yoktur. Nergis, arkadaşlarının ön ayak olmasıyla ilk kocası Çağdaş ile evlenmeden önce birlikte olur. Bunun ardından Nergis, durumu önce babası ile konuşmak ister ama "Git başımdan geç kaldım zaten" (Tekin, 2019: 49) cevabını alır. Daha sonra annesine durumu anlatmaya çalışır ama o da "Aman babanla ilgiliyse söyleme" (Tekin, 2019: 49) diyerek onu yanından uzaklaştırır. Aile içindeki iletişimsizlik akrabalar arasında da vardır. Bu, Nergis'in teyzesi üzerinden gösterilir. Nergis ile Çağdaş arasında yaşananların Erice'de duyulması üzerine Nergis, teyzesinin yanına gönderilmek istenir. Bu defa teyzesi iki oğlu olduğunu ve onların başını belaya sokmak istemediğini belirterek Nergis'in yanına gelmesini istemez.

Ersel'in babası bir sendikacıdır ve örgüt üyeliği dolayısı ile dört sene hapishanede kalmış, hapisten çıktıktan sonra yavaş yavaş hayattan uzaklaşmış, alkol bağımlısı olmuştur. Bu nedenle Ersel'in babası ile ilişkisi yoktur. "İleri derecede alkol kullanan kişi sarhoş olmasının, birtakım taşkınlıklarının önüne geçemez. Bilinci kapandığı için eşine ve çocuklarına fiziksel ve sözlü şiddet uygulayabilir" (Tarhan, 2009:213). Tarhan'ın belirtiği alkolün etkileri Ersel'in babasında da görülür ve bu haliyle o, aile birlikteliğini imkânsız hale getirir. Bunun üzerine Ersel'in annesi ondan boşanır ve Serco'nun ağabeyi ile nikâhlanır. Her ne kadar Ersel'in annesi eski kocasını tedavi ettirmeye, içki parasını karşılamaya çalışsa da Ersel'in babası Erice'yi terk ve sonunda intihar eder.

Zeynur -Ersel ile birlikte yaşar sonra kızı Eda'yı bırakıp Ersel'in üvey amcası Serco ile kaçar- ilk kocası ile evliliğini beş yıl sürdürmüş bir kadındır. Yazar, aile içinde insanların birbirlerine değer vermemelerini Zeynur ve kocası bağlamında yansıtır. Buna göre Zeynur, hırsızlık yaptığı için aranan kocası ile gizlice buluşur. Ama buluştukları sırada kocasının telefonunu çaldığı adam gelir. Bu adam önce yere ateş eder sonra namluyu Zeynur'un kocasının kafasına doğrultur. Silah tutukluk yapınca Zeynur'un kocası, hamile karısını elinde silah olan bu adamın yanında bırakarak kaçar. Adamın bu davranışı gerçekte karısına hiç değer vermediğini gösterir; çünkü telefonu çalınan öfkeli adamın karısına ne yapacağını umursamamıştır.

Toplumsal yapının en küçük ve en kuvvetli birimi olan Türk ailesi, yüzyıllardır etkisi hissedilen politik, askeri ve ekonomik buhranlara rağmen toplumu ayakta tutan bir emniyet sübabı işlevini yerine getirmiştir (Ayverdi, 1976:274). Manves City'de aile, toplumsal değişim ve bunun bireye olumsuz yansıması sonucunda yukarıda sözü edilen işlevini yerine getirmesi bir yana sorunun kaynağı bir halde anlatılır. Yazar, bunu Zeynur'un çocukluğu üzerinden romanına yansıtır. Zeynur'un bir deftere yazdığı yazıları türlü sebeplerle romanın içine dâhil edilir. Bu sebeplerden birisi Ersel'in bu deftere göz atmasıdır. Böylece Zeynur'un çocukluğu gün yüzüne çıkar. Buna göre Zeynur'un ailesinde iflaslar ve alkolik babasının meydana getirdiği sıkıntılar görülür. Annesi ise otorite manyağ ve erkeksi güdülerle annelik yapmaya çalışan biridir. Zeynur'un üç tane de üvey kız kardeşi vardır. Anneleri ayrı babaları bir olan bu kardeşlerin yetiştirilmelerindeki farklılık kişiliklerine yansımış, bu da aralarındaki iletişimi olumsuz etkilemiştir. Sonuç olarak böyle bir ailede yetişen Zeynur, insanlarla sorunlar yaşayan ve hayatına dair doğru kararlar veremeyen bir insan haline gelir.

Manves City'de aile bağlamında dikkati çeken en önemli hususlardan biri akrabalıkların üvey kavramı üzerine bina edilmiş olmasıdır. Çünkü romanda çoğu kişinin annesi, babası, teyzesi ya da kaynanası üveydir. Örneğin Ersel, üvey babası Domatesçi Halil ile yaşar. Nergis'in de üvey annesi vardır ve "Hoppa bir kadın olduğunu ileri yaşlarında kavradığı önceki üvey annesinin (...)” (Tekin, 2019: 47) ifadesi ondan 
öncesinde de bir üvey annesi olduğunu gösterir. Serco, Ersel'in üvey amcası, Vedanur, Eda'nın üvey teyzesi, Çiğdem ise Nergis'in üvey kız kardeşidir. Aynı zamanda Çiğdem'in üvey kaynanası vardır. Bu durum romanda "Erice'de herkes herkesin üveyidir" (Tekin, 2019: 27) ve "bir mahalleye girseniz silme akraba, hepsi üvey" (Tekin, 2019: 27) şeklinde belirtilir.

Aile bireyleri arasında meydana gelen şiddet olaylarının dört temel çeşidi vardır: fiziksel şiddet, duygusal şiddet, cinsel şiddet ve ekonomik şiddet. Bu şiddet çeşitleri içinde aile yaşamında kendini en fazla göstereni ise fiziksel şiddettir. Aile içi şiddet denildiğinde daha ziyade erkeğin kadına yönelik şiddeti akla gelse de ebeveynlerin çocuklarına uyguladıkları şiddet de dikkat çekicidir (Başaran, 2014: 155). Latife Tekin, Manves City'de yukarıda sözü edilen aile içi şiddet türlerinden çocuğa şiddeti "üvey olma" durumunun bir sonucu olarak ön plana çıkarır. Ersel, fabrikada çıkarılan yangın dolayısıyla beş yıl hapiste kalır. Bu süre içinde birlikte yaşadığı Zeynur geride kızı Eda'yı bırakıp Ersel'in üvey amcası Serco ile kaçar. Ersel hapisten çıktıktan sonra uzun zamandır kendisinden haber alınamayan Eda'yı aramaya başlar. Bu araştırma sırasında bir gün Ersel, Gülyaz Abla'nın konağına gider. Gülyaz Abla onu tanır. Yazar, bunu belirtirken Ersel'in üvey babasından gördüğü şiddete değinir: "Himalaya Ersel'i, akılsızı kim tanımaz! Çocukluğundan gençliğine, babasının ağaçta asılı bulunup gariplerin mezarlığına gömülmesine, annesine ve ona babalığının ettiği eziyete kadar her şeyini herkesten iyi biliyor" (Tekin, 2019: 63).

Ersel, Gülyaz Abla'nın konağında çok sayıda kedi ile karşılaşır. Bu durum Ersel'e kedi besleyen ve onlara ciğer getiren üvey babasını hatırlatır. Yazar bunu ifade ederken üvey babasının Ersel'e uyguladığı şiddeti göstermiş olur: “( ...) babalığı gazete kâğıdına sarılmış, kanlı ciğerler taşırdı boyuna. $\mathrm{O}$ akciğer kokusunun yüzüne tokat gibi çarptığı olurdu bazen, kedilere gösterdiği merhametin binde birini Ersel'e göstermez, onu dövmek için fırsat kollardı adeta, pek sevmezdi kedileri o yüzden” (Tekin, 2019: 63).

Yazar, aile içi sorunlardan en fazla etkilenenlerin çocuklar olduğunu Zeynur'un kızı Eda üzerinden gösterir. Zeynur, Serco ile kaçtıktan sonra kızı Eda, Serco'nun nikâhsız karısı Nergis tarafından yetiştirilir. Zeynur ile Eda, internet üzerinden iletişim kurarlar ve Zeynur, Eda’yı onu yanına alacağı yalanı ile oyalar. Yazar, “(...) nerede internet açıksa gölgesi oraya düşüyordu Eda'nın, Fotokopi Kâmil'den annesine bağlanacak diye yürüdüğü yol, akıttığı gözyaşı arşa ulaşırdı, üç koca yıl yalan sözlerle heveslendirip oyalamıştı kızını Zeynur"(Tekin, 2019: 25) ile Eda'nın anne hasretini internet ile giderme çabasını, bu ayrılığın onun çocuk yüreğinde açtığı yarayı ve hayal kırıklığını anlatır.

Zeynur'un kızı Eda'nın sorumluluğunu üzerine alan Nergis'in ilk kocasından iki oğlu vardır; Cesur ve Celil. Yazar, Cesur, Celil ve Eda arasındaki bir konuşmayı Nergis'in ağzından ifade ederken çocukların ruh durumunun anne babalarının ilişkilerinden nasıl etkilendiğini gösterir: "Çocuklar aralarında konuşuyormuş bunu, diyerek anlatmaya devam etti Nergis, 'Eda benim oğlanlara, 'öz babanız sakın gelmesin, gelirse beni sizi sevdiği gibi sevmez diye korkuyorum' diyormuş, benimkiler de ona 'Biz de annemin bir adam bulup gitmesinden korkuyoruz, yine ayrılırsak’ diyorlarmış” (Tekin, 2019: 37-38).

Kemal Çakmaklı çocuğun başarılı bir hayat sürmesinde anne ve babasının etkisini şu şekilde ifade eder: "Çocuk arkasında ana ve babasının desteği, önünde ise onların kuvvetli tecrübe ve bilgisi bulunduğu müddetçe başarı yolundadır" (Çakmaklı, 2009: 66). Bu bağlamda, annesi tarafından terk edilen, babası ile olumlu bir iletişim imkânı bulamayan, onların kuvvetli tecrübe ve bilgisinden mahrum kalan Eda'nın yanlış kişilerle gayrimeşru bir hayata yönelmesi kaçınılmaz bir son olur.

İlgisiz aile içinde dünyaya gelen ve büyüyen çocukların duygusal içtepileri ile hareket ettikleri, okula devam etmedikleri, zamanın değerlendirilmesinde sorun yaşadıkları, yanlış kişilerle arkadaşlık kurdukları, zararlı alışkanlıklara eğilimli oldukları görülür. Bunun yanında ilgisiz anne ve baba ile büyüyen çocukların yetişkinlik dönemlerinde hoşgörüsüz, anlık ve geçici doyumların peşinde koşan, günlük olayların içinde kendilerini kaybeden bireyler oldukları fark edilir (Özgüven, 2001: 215). Manves City'de anlatılan kişiler de sorunlu anne-babaların çocukları olarak büyümeleri dolayısıyla düzenli bir eğitim alamamış, yanlış 
kişilerle arkadaş olmuş hatta evlenmiş, günlük olayların içinde kendilerini kaybetmiş insanlar olarak romanda yer alırlar.

Sonuç olarak Manves City'de Latife Tekin, Türk toplumunun önemli unsurlarından biri olan aileyi, bireylerin iletişim sorunu yaşadığ çevre olarak aktarır. Bunun yanında Manves City'de ebeveynler arasında yaşanan sorunların çocukların duygu dünyalarını olumsuz etkilediğine değinilir. $\mathrm{Bu}$ ise çocukların hayatın ileriki dönemlerinde yanlış kararlar veren bireyler olmasının en önemli sebebidir. Romana yansıyan bu haliyle aile, Türkiye'de sorunların ve mutsuzlukların kaynăğdır.

\section{TÜRKIYY'DEKİ ÇALIŞMA HAYATININ MANVES CITY'E YANSIYAN HALİ}

Latife Tekin, Manves City'ye Türkiye'deki çalışma hayatını, yaşanan birtakım sorunlar çerçevesinde yansıtır. Bu sorunların başında işçilerin işverenler tarafından fazla çalıştırılması gelir. Romanda işçilerin baharın yaza dönmeye başladığı zamanlarda doğanın içinde yer alıp "bir ot toplamalık izin kullanma hakları"(Tekin, 2019: 40)nın olmadığ1 vurgulanır. İşçiler cumartesi günü tam gün çalıştıkları gibi gece mesaiye de kalırlar. Bu fazla çalıştırmanın altında da adı konulmamış bir şantaj vardır; çünkü işçiler kendilerine verilmeyen altı aylık maaşlarını alabilmek ümidiyle işverenin talimatı dışına çıkmaktan çekinirler. Bu ise onları adeta işverene esir eder.

Romanda işçilerin fazla çalıştırılmaları türlü sebeplerle zikredilir. Romanın başkişilerinden Nergis, bir süre Erice'den ayrılır, döndügünde ise kâğıt fabrikasında çalışmaya başlar. $\mathrm{O}$, öncelikle fabrikada üretimde hedeflerin sürekli yükseltilmesi suretiyle işçilerin daha fazla çalıştırıldığını fark eder. Bunun yanında fabrikanın şikâyet kutusuna atılan notlardan işçilerin tuvalet izninin toplamda on beş dakika olduğu, işçilerin tuvaletlere kart basarak girdikleri, tuvalette fazla kalmaları durumunda performans karnelerine eksi puan yazıldı ̆̆ı, bundan dolayı da ücretlerinde kesintiye gidildiği anlaşılır.

Nergis'in yaşam şartlarından söz eden yazar, bu vesile ile onun çalıştığı fabrikada Her İşe Koşan İşçi uygulamasından söz eder. Buna göre işçiler uykusuzluktan yıkılana kadar çalıştırılır. Bu zorlu çalışma şartlarının işçilere sunulma şekli ise sürekli gelişim parolası iledir. Nergis, Ersel'e hapisten çıkıp Erice'ye geldiğinde karşılaşacağ iş̧̧̧ileri şu şekilde betimler: "Sıra düzeni iş yetiştirmeye oturmuş yüzlerce işçiden ne bir ses ne bir işaret" (Tekin, 2019: 14).

Türkiye'deki çalışma hayatına dair Manves City'e yansıtılan bir unsur ise işçilerin emeklerinin karşılığını alamamalarıdır. Yazar, bu sorunu Ersel ve Nergis üzerinden şu şekilde ifade eder: "Hak ettikleri paranın ödenmediği ne çok atölyenin kapısında bekleyip elleri boş dönmüşler, uç uca eklesen aylar eder, hesaplamayı yüreği kaldırmıyordu şimdi, iş arayıp bulsalar, yarı senesi dolmadan hak aramaya çıkıyorlardı"(Tekin, 2019: 20). Çalışanların emeklerinin karşılığını alamamaları sorunu, Ersel'in Erice'nin gençlerinden Muhammet ve Abdullah ile konuşması sırasında da vurgulanır. Abdullah'a göre biri kesim diğeri dikiş makinesi alıp iki kişi bir atölye açar ve zor durumda kaldıklarında atölyeyi kapatıp kaçar; işçiler ise çalıştıkları günlerin karşılı̆̆ını alamaz.

Romanda dışarıdan Erice'ye gelen insanlar, hâlihazırda fabrikada çalışan işçiler üzerinde işten atılma kaygısını tetikler. İşten atılma kaygısı ise işçiler arasında rekabet hatta düşmanlık olarak kendini gösterir. Nergis'in de çalıştığı fabrikada işçiler amirlerinin talimatıyla bölünüp gruplara ayrılır. Bu gruplar, performanslarına göre ücret alacakları için bir yarışa girerler. Bu yarış ortamı ise insanlar arasında gerilime hatta düşmanlığa yol açar. Sunarteks'te bir zamanlar vardiya amirliği yapan ama şu anda bir takside şoförlük ile geçimini sağlayan İrfan Usta'ya göre fabrikada kaizen adı verilen bir uygulamayla işçi, işçinin düşmanı haline getirilmiştir.

Manves City'de işçilerin öneri kutusundaki yazılarından hareketle fabrikadaki rekabete dayalı çalışma şartlarını işçilerin benimsedikleri hatta performanslarından ötürü ikramiye ve ödül beklerken atık mal/hatalı üründen dolayı cezalandırıldıkları, bunun sebebini de kendilerinden önceki grubun seri bir şekilde iyi ürün 
gönderememesine bağladıkları görülür. Ara bölümden olmaları nedeniyle kayıplardan sorumlu tutulmak istemeyen işçiler, başlarında kronometreyle deneme yapılmasını ve üretim bandında akışı aksatan bölümün işçilerinin cezalandırılmasını isterler.

Gelecek on on beş y1l içinde otomasyon sonucunda mevcut iş pozisyonlarının \%5 ile \%15 arasında ortadan kalkacağı ön görülmektedir (Frank, Roehrig \& Pring, 2019: 51). Mevcut iş pozisyonlarının ortadan kalkmasının doğal bir sonucu ise işsizliğin artmasıdır. Otomasyon ve ardından gelecek işsizliğin romanda işçiler üzerindeki etkisine de yer verilir. Ersel, hapiste karşılaştığ Afgan Amir'in vesilesi ile Erice'de Azimet Bey'in çiftliğinde işe girer. Burada veteriner Ogün Bey ile Ersel arasındaki konuşmada Erice'de insansız fabrikaların kurulacağı, işsizliğin artacağı belirtilir. Bu durumu Ogün Bey şu şekilde ifade eder: "Buradan bizim çiftliğe kadar satın aldılar, karanlık fabrika kuracaklarmış, insansız fabrika, enerji tüketimi sıfir, robotlar yapacak üretimi, Erice'nin nereye gittiğini düşünüp hayal etmeye çalış bu söylediğimden, eskisi gibi iş bulmak kolay olmayacak öyle, (...)" (Tekin, 2019: 60) Amirlerin, işçileri tahkir derken bu gerçeği vurguladıkları da görülür. Örneğin saha sürveganı, robotlaşmaya gidileceğini ima ederek yakında işçilere ihtiyaçlarının olmayacağını ve hepsini sokağa dökeceklerini ifade eder.

Yazar, işçilerin şikâyet kutularına attıkları mektuplarda dile getirdikleri istekler üzerinden işçilerin makine ya da robot olmadıklarını vurgular. Bu mektuplardan birinde iş̧̧iler, fabrika yönetiminden mesai dışında süs havuzunu temizleyebilmek için izin isterler. İşçilerin böyle bir işe istekli olmaları göz zevklerinin olduğunu ve fabrika yönetiminin ise buna dikkat etmediğini gösterir. Bunun yanında işçilerin yemekhane duvarında manzara resminin olmasını, dans ve kick boks kursu açılmasını, tiyatro kulübünde yer alan işçilerin vardiyalarının ayarlanmasını istemeleri ile klima odasında namaz kılmaya ve yirmi dört saat kameralar tarafından izlenmeye karşı çıkmaları, makineleştirilmek istenen insanın buna karşı çıkışı olarak sergilenir.

"Sendikalar; üyelerinin çalışma hayatındaki sorunlarını çözen, haklarını ve ortak çıkarlarını koruyup geliştirmek için kurulan örgütlerdir” (Yıldız, Zengin \& Karagöz, 2018: 94). Bu bağlamda Latife Tekin'in romanına yansıttığı çalışma hayatına dair bir unsur da işçilerin karşılaştıkları sorunları çözebilmek, haklarını ve çıkarlarını korumak ve geliştirmek maksadıyla sendikalaşamadıklarıdır. Nergis'in çalıştığı kâğıt fabrikasında iş̧̧iler "Çıt çıkarmadan gizli şekilde" (Tekin, 2019: 41) sendikalaşmaya başlar. Buna rağmen fabrikada takipçi adı verilen kişi bu faaliyetten haberdar olur ve bir süre sonra sendikaya kimlerin üye olduğu öğrenilir. Bunun ardından bu sendikalı işçilerden kimisi vaatle kimisi tehditle sendikadan istifa etmeye zorlanır. Ersel'in sendika temsilcisi olduğu öğrenildiğinde ise o ve beş arkadaşı işten çıkarılır.

Ersel ve arkadaşları, işten çıkarılmaları kararına direnip de çevrelerinde diğer işçileri toplamaya başladıkları anda Ersel, fabrikayı kundaklama suçuyla tutuklanır. "Kapıyı kilitleyip depoyu ateşe vermekle suçlanıyordu, ortada ölüm olunca Ersel'den yana şahitlik etmeye ürkmüştü insanlar. Yangın sırasında birilerinin kaçtığını gördüklerini söyleyenler de susmuştu sonra." (Tekin, 2019: 43) şeklinde durumu anlatan yazar, bu işin içinde fabrika sahiplerinin olduğunu "Küçük patron Vedat'ın arka bloktan çıkıp gittiğini fisıldayanlar olmuş.” (Tekin, 2019: 43) ifadesi ile belirtir. Bu olayın ardından Ersel, hapse atılırken eyleme katılmış olan işçiler işe başlar: "(...) soğutma işlemi sürerken fabrikanın ana üretim binasında işbaşı yapılmıştı bile" (Tekin, 2019: 44). Ayrıca sendikaya üye yüz işçi de işten atılır. İşçilerin bu durum karşısında bir şey yapamadıklarını ise yazar şu şekilde ifade eder: "Alacağımızdan kırptıkları paralar haram olsun; dediler, nefesleri güçleri daha fazlasını söylemeye yetmedi” (Tekin, 2019: 44).

Latife Tekin, kadınların çalışma hayatında karşılaştıkları zorlukları romanına yansıtır. Fabrikada çalışan kadınlardan birinin, üretim şefinin tokat atması üzerine eylem yapan ve sonuçta işten çıkarılan nişanlısının ardından yaşadıkları buna örnektir. Öncelikle bu kadının fabrikadaki şikâyet kutusuna attığı mektubundan daha sonraki süreçte nişanının bozulduğu öğrenilir. Çünkü adam nişanlısının da işten çıkmasını istemiş, kadın kabul etmeyince de nişan bozulmuştur. Aynı mektupta fabrika ustalarından Atagün Usta'nın bu genç kadını rahatsız etmeye başladığı görülür. Bu genç kadın, Atagün Usta'nın kendisine tecavüz etmesinden, 
bunu kimseye izah edemeyecek olmasından endişelidir. Çünkü Atagün Usta fabrikada hem üretim şefidir hem de fabrikanın imamıdır.

Manves City'de çalıştıkları fabrikada işçilerin en temel ihtiyaçlarının karşılanmadığı görülür. Nergis'in mektubundan anlaşıldığ üzere işçiler fabrika yönetimini sebil aldırmaya zorlar; çünkü fabrika yönetimi işçilere günde yarım litre su vermekte ve bu, yüksek sıcaklıkta çalışan işçilere yeterli gelmemektedir. Bu konuda 1srar eden işçilere fabrikanın müdürü sabırlı olmalarını salık verirken performans düşüklüğünü bahane ederek işçileri kovmakla da tehdit eder. Bunun yanında elleri ağızları yandığı için naylon bardakta çay içmek istemeyen işçiler, gece vardiyasında dört zeytin bir domatesin de kendilerine yetmediğini dile getirirler. İşçilerin şikâyet kutusuna attıkları mektuplarından fabrikanın yemekhanesinde hijyene dikkat edilmediği, bazı işçilerin evlerinin uzak olması ve tek servisle bütün işçilerin alınması dolayısıyla fabrikaya gelişlerin üç dört saati bulduğu; buna karşın fabrika yönetiminin ek servis çıkarmadığı anlaşılır. Bu mektuplarda ayrıca işçilerin kimi kişisel tercihlerinin çalışma hayatlarını olumsuz etkilediği görülür. Örneğin dövmesi olanlara mesai hakkı tanınmadığı gibi erkek işçilerin küpe takmasına da izin verilmez.

Yazar, işçilerin öneri kutusuna attıkları yazılara yer vererek onların bilinç alanına 1şık tutar. İşçiler bu yazılarda her ne kadar insani şartlarda çalışma noktasında sıkıntılar yaşasalar ve bu yönde değişiklik isteseler de sistemin işleyiş̧ine ve bu sistemin sahiplerinin üstünlüğüne boyun eğmiş gösterilir. Bunun örneği ise işçilerin patronla selfie çektirme sırasına girmiş olmaları ve bu konuda aralarında tartışmaların yaşanmasıdır. İşçiler, patronun helikopterinin her iniş ve kalkışında yaşadıkları heyecandan yorulduklarını belirtirken sıranın bir an önce kendilerine gelmesini isterler. İşçilerin çalışma hayatında sistemin işleyişini kabullenişlerine bir örnek de fabrikada uygulanan 6 sigma ve kaizen sistemi ile ilgili eğitim almak istemeleridir.

Yazar, işçilerin içinde bulundukları çalışma şartlarını benimsediklerini Başarının Sırrı konulu yarışmaya gönderilen bir yazı üzerinden gösterir. Bu yazıda -kim tarafından yazıldığı belirtilmemiş- işçi/yazar, öncelikle başarıyı kadere bağlar. Bu, onun yaşananları kabullendiğinin bir işaretidir. Bunun yanında o, çok yorulsa da karşılığını aldığı takdirde kendini başarılı görür. Bunun hemen ardından da aza kanaat etmenin çoğu bulmanın yolu olduğunu belirtir. Böylelikle işçi/yazar, çok yorulup az kazanmayı kendi bilinç dünyasında anlamlı hale getirir. Bu yazıda başarının bir sırrını işçi/yazar, ustanın kaprislerini çekebilmeye bağlar. Bu yazıyı yazan işçi/yazar, iyi olduğuna ve daha iyisini hak ettiğine inanıp okyanusa açılırsa ya boğulacağını ya da şansı varsa ayrıldığı kıyıya geri döneceğini ifade eder. Böylece Latife Tekin, bu işçi/yazar üzerinden bazı işçilerin çalışma sisteminin parçası olmaya hevesli olduklarını gösterir.

Sonuç olarak çalışma hayatı bağlamında Türkiye, Manves City'e işçilerin fazla çalışmak zorunda kaldığı, emeklerinin karşılığını alamadıkları bir ülke olarak yansır. Romanda çalışma hayatı içinde işçiler arasındaki rekabetin düşmanlığa dönüştüğü fark edilir. Bununla birlikte fabrikalardaki rekabetçi sistem işçiler tarafından benimsenmiş̧tir. Romanda otomasyonun işçiler üzerinde bir tehdit unsuru olduğu, sendikalaşmanın ise işverenler tarafından engellendiği ifade edilir. Ayrıca Manves City'de iş yaşamında kadınların yaşadıkları sorunlar ile işçilerin iş yerlerinde yeterli su, yemek temini ve ulaşım noktasında sorunlarının olduğu belirtilir.

\section{MANVES CITY'E YANSIYAN TOPLUMUN MANEVİ DEĞERLERINII KAYBETMIŞ HALİ}

Toplumu oluşturan bireyleri bir arada tutan unsurların başında o toplumun manevi değerleri gelir. Bireyler, toplumun tarihsel bir süreçte oluşturduğu bu değerler üzerinde adı konulmamış bir uzlaşı içindedir. Böylece birey toplum içinde nerede nasıl davranması gerektiğini bu değerlerin rehberliğinde bilir. Bu bağlamda Âmiran Kurtkan manevi değeri "büyük bir sosyal grubun mensuplarının (sırf başkaları tarafından tasdik edildiği için değil) kendi idrak ve anlayışları ile doğruluğunu tasdik ettikleri için anlaşma halinde oldukları ve sübjektif olarak da kıymet takdir ettikleri değer hükümleridir" (Kurtkan, 1977: 7) şeklinde tarif eder. Manves City'de Latife Tekin, toplumu oluşturan bireyleri bu manevi değerleri kaybetmiş bir vaziyette 
anlatır. Yazar, türlü vesilelerle bu olumsuz halin örneklerini verir. Bunlardan biri Afgan Amir ve karıs1 Bahal bağlamında romana yansitılır.

Amir, Afganistan'dan karısı Bahal ile Türkiye'ye gelmiş, Erice'de bir çiftlikte çalışmaya başlamış bir göçmendir. Bir tartışma neticesinde cezaevine düşmüş, yirmi yıl ceza almıştır. Çalıştı̆̆ fabrikada çıkarılan yangın dolayısıyla kendisine iftira atılan Ersel ile Amir, cezaevinde tanışır. Amir, güvenilebilecek biri olarak gördügü Ersel'i dışarıda emin ellerde olması için genç karısı Bahal ile birlikte olmaya yönlendirir. Yazar bu durumu “Amir'le kaderleri benziyordu, onu Bahal'le konuşması için tembihlemişti, Bahal gençti daha, kendine yeni bir hayat kurmalıyd1, yeni bir eş bulup..." (Tekin, 2019: 54) ifadesi ile belirtir. Bu durum, topluma güvenini yitirmiş bir insanın sevgisini ve gururunu ayaklar altına alıp karısını koruma çabasını gösterir.

Yazar, insanları bir arada tutan değerlerin kaybolduğunu Ersel ve Eda bağlamında da dikkatlere sunar. Eda adındaki üvey kızını hapisten çıktıktan sonra arayan Ersel, Gülyaz Abla'dan bilgi alır. Buna göre Eda, bir süre üvey teyzesi Vedanur'un yanında kalmıştır. Vedanur sevgilisi ile birlikte ev açmak için borçlanmış, sevgilisi tarafından terk edildikten sonra muhasebeci Âdem ile düşüp kalkmaya başlamış üstündeki borcu ödeyemediği için de hapse girmiştir. Gülyaz Abla'dan Eda'nın teyzesini çıkarmak için yanlış insanlarla bir araya geldiği öğrenilir. Eda, Selim adında bir avukat vasıtasıyla Kiremitçi Bekir ile tanışır. Bu adamın Eda'ya teklifi toplumsal yozlaşmayı sergiler: "Teyzeni bir sözümle bıraktırırım, ama teyzen benim sevgilim olacak, sen de Selim'in, tamam mı?” (Tekin, 2019: 64)

Toplumdaki olumsuz değişim, insanların olayları değerlendiriş tarzına sirayet eder. Yazar, insanlarda iyi niyetin kalmadığını yine Ersel ve üvey kızı Eda çerçevesinde romanına dâhil eder. Ersel, üvey kızı Eda'yı düştüğü fuhuş çukurundan kurtarmak için bütün iyi niyeti ile çabalarken insanlar bunu yanlış anlar. Ersel'in kızını aradığını söylediği Salih Usta'nın sonrasında şaka olduğunu söylese de “(..) kız senin kızın olsa arama demem de, başkasının kızını arayana bizim millet iyi gözle bakmaz, nikâh kıyıp düğün mü yapacaksın diye sorarlar, (...)"(Tekin, 2019: 110) sözü bireysel çürümenin bilinçaltının derinliklerinden yüzeye sızmış hali gibidir. Buna benzer bir ifade, Ersel'e Eda'ya ait fotoğraflar gösteren ve Eda'nın yanında olduğu düşünülen Vedat'ın eşinden de gelir: “(...) fotoğraflar göstereceğim şimdi, lütfen bakmak istemezseniz söyleyin ama aynı kızdan mı söz ediyoruz bilmemiz lazım, insan üvey kızını niye öyle arasın diye düşününce" (Tekin, 2019: 137).

Ahlaki değerlerdeki erozyon, romanda gayrimeşru ilişkilerin yaşandığı mekânların yerleşim yerlerine yaklaşması ile de gösterilir. Bu öyle güçlü bir dalgadır ki bu mekânların yerleşim yerlerine yaklaşmasını toplumda sözü geçen insanlar dahi engelleyemez. Yazar, bu durumu Ersel'in, Azimet Bey'in çiftliğinde çalışmaya başlaması vesilesiyle dile getirir. Ersel, çiftlikteki ilk gecesinde uyuyamaz; çünkü yakından müzik sesleri gelir. Veteriner Ogün Bey, bu müzik sesinin pavyonlardan geldiğini ifade eder. Bu durumdan hoşnut olunmadığı, bunların kapatılmasına çalışıldığı ancak buna ilçenin ileri gelen simalarından Azimet Bey'in dahi gücünün yetmediği Ogün Bey'in sözlerinden anlaş1lır: "Maalesef müzikhollerimiz var burada, pavyon dememek için öyle söylüyoruz artık, çok uğraştık kapattırmak için, Azimet Bey çalmadık kapı bırakmad1, o bile diş geçiremedi adamlara, sözü dinlenen birkaç insandan biridir, (...)” (Tekin, 2019: 5859)

Azimet Bey'in pavyonların açılmasına engel olmaya çalıştı̆̆ını belirtilmesine karşın asıl ahlaki değer yitimine uğrayan Azimet Bey’in kendisidir. Çünkü Azimet Bey'in zamparalı̆̆ı yüzünden çiftliğine baskın düzenlenir. Bu baskınlardan birinde çiftliğin çalışanlarından Afganistanlı Amir, hapse düşer. Onun bu fedakârlığına karşın Azimet Bey, Amir'in genç eşi Bahal ile gönül eğlendirir.

Toplumu bir arada tutan değerlerden biri adalettir. Latife Tekin'in romanına yansıttığı toplumda adaletsizlik o noktaya gelmiştir ki çocuklar için düzenlenen festivalde dahi çocuklar arasında ayrım yapılır. Bu bağlamda yazar, Nergis ile Ersel'in çocukluklarına dair bir anıyı dile getirir. Kasabada gerçekleştirilen 
Kiraz Festival'ine Yemişlik Mahallesi'nden topluca gidilir. Bu festivale Yağderesi'ne kurulmuş fabrikalar da destek vermiş, Manves adlı şirket televizyon fabrikasının açılışı ile festivali bir araya getirip bir eğlence park1 kurmuş ve çocuk oyunu getirmiştir. Bu eğlencede palyaçolar çocuklarla oynarken onlara oyuncaklar da verir. Ne var ki Ersel ve Nergis, oyuncak alamazlar ve annelerinin eteğine yapışırlar. Ersel'in annesinin palyaçoya ifadesinde çocuklara oyuncak dağıtımında yukarıda sözü edilen adaletsizliğin izi görülür: "Bizimkilerin bir teki bile oyuncak alamad1, oyuncakların hepsini müdürlerin, şeflerin çocukları aldı, bak şunların yüzüne, (...)” (Tekin, 2019: 48)

Latife Tekin, kimi manevi değerlerin yok oluşunun hem bir sonucu hem de sebebi olan insanın nesneleşmesini Nergis üzerinden anlatır. Yazar, Nergis'in nikâhsız kocası Serco'nun, Zeynur ile kaçması ardından Nergis'in güçlü durması gerekliliğinden söz eder. Güçlü olamayan insan fabrikada bozuk mal gibi hayattan süpürülür: "Gücü tükenecek olsa banttan süpürülen bozuk mal gibi ayıklanacaktı, hatalı ürün deposundan Erice pazarına indirilen ucuz mala dönmekten kim korkmaz ki, aylarca yüreği ağzında gidip gelmişti işe" (Tekin, 2019: 16). Böylece yazar, insanlar arasında yardımlaşmanın kalmadığı, güçlünün zayıfı ezdiği bir düzenin hâkim olduğu bir toplumu romanına dâhil eder.

Rekabetçi hayatın bir sonucu olarak liberal ekonomi üzerine inşa edilmiş toplumlarda insanların kendi menfaatlerini ön plana çıkardıkları görülür. Bu noktada Orhan Türkdoğan şu tespitte bulunur: "(...) sağlıklı olmayan liberal ekonomik gelişmeler de fertlerin vicdani kararlarında, dünya görüşlerinde, davranış ve moral değerlerinde köklü sarsıntılar meydana getirmek suretiyle kendi çıkarını düşünen yeni bir homoekonomik zihniyetin filizlenmesine yol açmaktadır" (Türkdoğan, 1996: 159). Manves City'de Erice'deki ekonomik gelişmenin sonucu olarak hayatta kalmayı tek amaç haline getiren, diğer insanların yaşamını ikinci plana atan bu homo-ekonomik zihniyet anlatılır. Bu zihniyete ayak uyduramadığ 1 içindir ki üvey kızını arama mücadelesi veren Ersel en nihayetinde bu sistemin dışına itilir.

\section{TÜRKIYE'DE GÖÇ OLGUSUNUN MANVES CITY'E YANSIYAN HALI}

Manves City'de Latife Tekin, Erice'ye göçün etkilerini yansıtır. Ersel, Azimet Bey'in çiftliğinde hapishanede tanıştığı Afganistanlı Amir'in yönlendirmesi ile iş bulur. Ersel'in Amir'in karısı Bahal ile konuşmasından çiftlikte çalışan Suriyeli ailenin ilçede çıkan olaylar sonucunda ilçeden ayrıldığı öğrenilir. İlçeden ayrılan bu Suriyeli ailenin yerine yeni bir Suriyeli ailenin bulunduğunu da ekleyen yazar, bu Suriyeli aile ve Afgan Amir'in varlıkları ve yaşadıkları ile Türkiye'ye farklı ülkelerden göç edildiğini ve gelenlerin de türlü suçlara karıştığını ifade eder. Bunun yanında yazar, göçmenlerin Erice'de hırsızlık ithamlarının hedefi olduğunu ancak bu hırsızlıkların on yıl önce de meydana geldiğini Nergis'in gazete köşesinde yazdığı yazı bağlamında şu şekilde dile getirir:

“(...) Bildiğimiz ama üstünden geçilmesi gereken durumlardan bir tanesi, göçmenler. Evsizler için avantajlı bir ilçe burası, yazın serin, kışın korunaklı, ılık. Bu hırsızlık olayları yeni değil, on yıl önce de firın soyuluyor, arı kovanı çalınıyordu, kargı kulübeleri, bostan bekçilerini hatırlayanlara sorarsanız size o eski hırsızlıkları anlatırlar, kalbimizi bozmayıp dilsiz sessiz göçmenlere tercüman olmaya çalışalım” (Tekin, 2019: 57).

Romanda her suçun göçmenlere bağlanmaması belirtilse de göçün aile yaşamını dahi etkileyen bir olgu olduğu gösterilir. Şöyle ki Nergis, Serco'nun Zeynur ile kaçması üzerine bir adam ile birlikte olur. Bu adam Tunuslu bir kız ve yanındaki annesini evine alır. Nergis ile Tunuslu kızın annesi kavga eder ve bu kavgada Nergis'in yüzünde kesik oluşur. Bunu Ersel, Gülyaz Abla ile konuşurken öğrenir: "Ersel, Nergis'in yüzündeki kesikle ilgili yalan söylediğini öğrendi Gülyaz Abla'dan, gittiği adamın eve getirdiği Tunuslu kızın annesi kesmişti yüzünü, ölebilirdi de..." (Tekin, 2019: 64)

Latife Tekin, Türkiye'deki göç olgusunu, yurtdışından gelen göçmenler bağlamında romanına yansıtır. O, bu göçmenlerin türlü suçlara karıştığını belirtse de ülkede işlenen her suçta bu insanların payının olmadığını 
da vurgular. Bununla birlikte Manves City'de yurtdışından Türkiye'ye göç, ülke insanının aile yaşamına değin etkileri olan bir olgu olarak romana dâhil edilir.

\section{MANVES CITY'DE KADINLARIN SORUNLARI}

Manves City'de kadınlar, içinde bulundukları toplumda karşılaştıkları kimi sorunlar bağlamında anlatılır. Bu sorunlardan ilki, kadınların bir erkeğin himayesi olmadan çocukları ile kendi ayakları üzerinde durmaya çalışırken karşılaştıkları zorluklarla ilgilidir. Nikâhsız yaşadığı Serco'nun Zeynur ile kaçmasının ardından Nergis, iki oğlu ile Zeynur'un kızı Eda'yı yanına alır ve onlarla yaşamaya başlar. Ne var ki toplum, başında bir erkek olmadan bir kadının ayakları üstünde durma çabasına alışık değildir. Yazarın "Serco'nun Zeynur'la gidişinin ardından uygunsuz tekliflere açık hale gelmişti, işsizlik günlerinde üstündeki baskı daha da yoğunlaşmış" (Tekin, 2019: 46) dediği Nergis, başta hiçbir erkekle bir araya gelmeyi düşünmese de sonunda "Hayatımı birleştireceğim iyi bir adam bul bana, geçici olarak" (Tekin, 2019: 26) diyerek Gülyaz Abla'nın aracılığı ile bir adamla birlikte olmaya mecbur kalır. Ne var ki Gülyaz Abla'nın bulduğu ve hastalı derecesinde kadınlara zaafı olan bu adam, göçmen bir anne kızı evine alır. Belli ki zor durumda kalan sadece Nergis değildir. Çünkü bu göçmen anne ve kız da içinde bulundukları zorlu şartlardan kurtulmanın yolunu bir erkeğin himayesine girmekte bulmuştur. Bu ise erkeklerden bağımsız varlıklarını sürdürme noktasında kadınların yaşadığı zorlukların Türklere mahsus olmadığını gösterir.

Manves City'de kadının erkekten gördüğü şiddete de yer verilir. Ersel, üvey kızı Eda'yı ararken Eda'nın teyzesi Vedanur ile konuşur. Bu konuşmanın başında Vedanur yüzündeki yarayı şu şekilde açıklama ihtiyacı duyar: "Eski yüzümle şimdiki yüzümün alakası yok, bu bıçaklanmış halim, şerefsiz bir de âşığım sana diyerek saplıyordu, (...) otuz yedi defa ameliyat geçirdim(...)" (Tekin, 2019: 108) Bu noktada ilginç olan Vedanur'un maruz kaldığı şiddete karşı ne yapabileceğini düşünmeyip ayda iki bin lira verip bir hafta kendisi ile beraber olmayı isteyen adama gitmediği için pişmanlık yaşamasıdır.

Ersel ile yaptığı konuşmada Vedanur, Eda'nın -Nergis'in birlikte yaşadığı adamın tacizine de uğramıştırNergis'in oğlundan kaçıp kendisine sığındığına değinir: “Eda'yı bulursan bana da haber et, en son Nergis'in oğlundan kaçıp yanıma geldiğinde gördüm onu, sabaha kadar gözünü kırpmamış, pazar tezgâhının altına kilim serip uyuttuk, (...)" (Tekin, 2019: 108) Vedanur'un bu sözleri, kadının yazgısını bir sonraki kuşağa aktardığını gösterir. İlginç olan Nergis gibi bilinç düzeyi yüksek, Erice'nin yerel gazetesinde yazıları yayımlanan ve erkeklerin gadrine uğramış bir kadının oğlunun da kendinden önceki kuşağın kimi erkeklerine benzer davranış sergilemesidir. Yazar, Ersel'in kendi kendine söylediği "İnsan başına gelince görmeye başlıyor, ne çok kesilip biçilmiş kadın varmış da dikkat etmiyormuşum meğer.”( Tekin, 2019: 109) ifadesi ile kadına şiddetin varlığının ancak başa gelince fark edilebildiğini vurgular.

\section{MANVES CITY'DE ŞEHİRLEŞME}

Şehirleşme Türk Dil Kurumu sözlüğünde "Özellikle sanayinin gelişmesi sonucu nüfusun şehirlerde toplanması ve şehir alanlarının genişlemesi süreci” (TDK, 2011: 2211) şeklinde tanımlanır. Bu tanıma uyan şekilde yazar, romanında şehirleşmenin Erice'de sanayinin gelişmesi, nüfusun hızla artması ve yerleşim alanlarının genişlemesiyle hızlandığını dile getirir. Erice'nin bu değişimi ise Ersel üzerinden romana dâhil edilir. Ersel, beş yıl hapiste kaldıktan sonra önceden çalıştı̆̆ 1 fabrikaya gelir. Ne var ki Ersel, fabrikanın kapısını bulmakta zorlanır. Bunu yazar şu şekilde belirtir: “Şu Ersel'in Yağderesi'ni dolaşıp da, o işçi deryası sanayi dünyasında, beş yıl önce çalıştığı fabrikanın kapısını bulamayışını kim anlatabilir ki?" (Tekin, 2019: 11) Bu değişim esnafların tabelalarına kadar sirayet eder. Bunu yazar eserine şu şekilde aktarır: "Ersel zorlamasa hatırlamak istemeyeceği şeyleri anlatıp duruyordu Nergis. Meydan Lokantası, 'Meydan Yemek Dünyası' olmuştu adı şimdi- Yavşanlı Mesire Yeri-‘Dostluk Bahçesi'-, At Pazarı Kahvesi -'Yüz'de 100 Kahve'- derken günün yarısını konuşup dertleşerek geçirdiler”' (Tekin, 2019: 26).

Köyden şehre göç, akrabalık ilişkilerinin ön planda olduğu, bireyin insanlar arasındaki konumunun çoğunlukla doğumla belirlendiği, toplumsal normların kaynağını geleneklerden aldığı cemaatten, akrabalık 
ilişkilerinin yerini çekirdek aileye bıraktığı cemiyete geçişi ifade eder. Şehirde toplumsal tabakalaşmanın en altında yer alan ve yukarı çıkma olanağı da bulamayan insanlar bu geçişten en fazla etkilenenlerdir. Toplumsallaşmayı ve toplumsal kontrolü sağlayan değerlerin kaybolmasının da etkisiyle şehirlerde alkolizm, uyuşturucu madde kullanımı ve intihar yanında suçlarda da artış olur (Bal, 2008: 136). Şehirleşme ile ortaya çıkan bu özellikler, Manves City'de de görülür. Erice, şehirleşme ile birlikte toplumsal değerlerin öneminin ve bireyler üzerindeki denetim gücünün zayıfladığı, akrabalık ilişkilerinin en aza indiği, alkolizmin önemli bir sorun olduğu yerleşim yeri olarak anlatılır. Bu olumsuz değişimin bir sonucu da Erice'de suç oranlarının artmasıdır.

Nergis, Erice'de bir gazetede köşe yazıları yazar. Onun bu gazetedeki bir yazısından anlaşıldığı üzere Erice'nin dumanı ve gazı kadar kuaför sokağında işlenen cinayetleri de dikkat çeker. Yine Nergis'in yazısına göre Erice'nin silah seslerinden geceleri uyunmaz hale geldiği anlaşılır. Ersel ile konuşmasında işten kovulduğu için taksicilik yapan İrfan Usta ise "Taksiciliğin de tehlikesi başka türlü, akşam Kirazcık yoluna bıraktığım adamı gece vurmuşlar, sabah geldim duraktan arkadaşımız Yemişlik’te bir çocuğu ezmiş, bakkala koşuyormuş, (...)"(Tekin, 2019: 68) der ve bunun sebebini "Tadı kaçtı buraların, çok insan doldu, (...)"(Tekin, 2019: 68) diyerek belirtir.

Büyük ya da büyüyen şehirlerde kimi insanlar küçük yerleşim yerlerinde işlevsel olan toplumsal denetimin baskısını yaşamazlar. Bundan dolayı bu insanların "Küçük köy topluluğunun oynadığı denetim işlevinin etkisi azaldığından, toplum için yararlı olmayan, hatta zararlı yollara kapılmaları olasılığı da artar" (Keleş, 2002: 74-75). Şehirleşme ile birlikte toplumsal denetimin azalmasının birey üzerindeki olumsuz etkisine ve bunun Erice'nin gündelik hayatına yansımalarına Nergis, Erice Postası'nda yazdığı yazılarında değinir. Nergis'in kaleminden öğrenildiğine göre Erice'de nüfus artmadan önce insanlar evlerde toplanıp çay sefası yapar, sabahları da neşeli bir şekilde fabrikaya, tarlaya giderler. Nüfusun artmaya başlaması ile işe gitmek için kadınlar minibüs beklerken önce kamyonet ve arabalardaki erkeklerin bakışlarına daha sonra pazara mal getiren satıcıların taşıtlarından gelen korna seslerine maruz kalırlar. Kadınlar bir süre sonra bu adamların pazarlarda elle tacizlerine de uğramaya başlar. En sonunda kadınlar Erice'de tek başlarına yürüyemez hale gelir; çünkü dışarıya çıktıkları zaman arkalarından birileri ıslık çalmaktadır.

\section{MANVES CITY'DE TABİATIN TAHRİBi}

Toplum, insanoğluna dair özelliklerin bir yansıma alanı olarak bir ekosistemdir ve diğer doğal ekosistemlerle ilişki içindedir. Bunun yanında kendine ait ekosistem ile diğer doğal ekosistemler arasında kalan sınır alanda insanoğlu üretimini gerçekleştirir ki bu sınır diğer doğal ekosistemlerin aleyhine genişlemektedir. Her ne kadar diğer ekosistemler bu genişlemeyi tamponlamaya çalışsa da insanoğlunun üretiminin olumsuz sonuçlarını telafi edebilme gücünü azaltan ve ekosistemlerde bir çöküşü işaret eden bir süreç ortaya çıkmıştır. İnsanoğlunun yeryüzünün tamponlama kapasitesini zorlaması ise telafisi mümkün olmayan sonuçlar doğuracaktır (Kovel, 2005: 41-43). Latife Tekin, Manves City'de insanoğlunun doğanın bu tamponlama kapasitesini aşma noktasına geldiğini anlatır.

Manves City romanında Nergis'in hapisteki Ersel'e yazdığı mektuptan anlaşıldığı üzere tabiat yavaş yavaş Manves adlı şirketin fabrikaları dolayısıyla yok olmaktadır. "(..) bizim gelincik tarlamız da bir dahaki bahara yok, Manves almış orayı da, (...)” (Tekin, 2019: 16) şeklinde yazan Nergis'e göre Erice'de sanayileşmenin artmasında çalıştırılacak sahipsiz ve yoksul insanın çok olması etkilidir: “(...) Erice'nin yoksulu sahipsizi bol nasıl olsa, işçi bulmaktan yana sıkıntı çekmiyorlar” (Tekin, 2019: 16).

Yazar, Manves City üretim tesislerinin Erice'de yayılmasında ve tabiatın yok olmasında bu şirketin toprakları ele geçirmek için zor kullanmasını da ön plana çıkarır. Çünkü romanda geçen “(...) Manves tüm ovayı kapladı, Azimet Bey'e bile çiftliği satması için baskı uygulanıyor, hem de Nise Hanım'ın akrabası tarafından." (Tekin, 2019: 59) ifadesi Erice'de sözü geçen çiftlik sahiplerinden biri olan Azimet Bey'in 
dahi bu baskıya maruz kaldığını gösterir ki en nihayetinde o, bu şirketlere "bağı bahçeyi, koca incirliği teslim et(mek)" (Tekin, 2019: 59) zorunda kalır.

Manves City'de tarım arazilerinin yok edilişinden de söz edilir. Nergis'in köşe yazısındaki “Büyüklerimizin yeşil deniz dediği Pırasa Ovamızda iki pulluğun döneceği kadar yer kalmadıysa, nereye gidiyoruz diye sorma vaktimiz gelmiş demektir." (Tekin, 2019: 44) ile yazarın Ersel'in Erice'de üvey kızı Eda'yı ararken doğanın tahrip ediliş biçimine dair "Ovayı bitki seraları gibi sıralanmış fabrika binaları kaplamış, askeriyenin baraka düzenine sokulmuştu tarlalar, seyredecek olana bir göz boşluğu bırakmak düşünülmemiş.” (Tekin, 2019: 66) ifadesi Erice'de tarım arazilerinin yok edildiğini gösterir.

\section{SONUÇ}

Manves City'de aile bireyleri arasında var olan iletişim eksikliği ön plana çıkarılır. Bu sorun hem aile içinde hem de akrabalar arasında güven eksikliğini ve bireylerin birbirlerine değer vermemesini beraberinde getirir. Mutsuz bir aile ortamında yetişen çocuklar sonraki dönemde mutsuz evlilikler yapar; bu evliklerden kaçış ise gayrimeşru ve gayri resmi ilişkilerin yolunu açar. Bu ilişkilerin olumsuz etkileri ise en fazla kadın ve çocuklar üzerinde görülür.

Çalışma hayatı bağlamında Manves City'de işçilerin fazla çalıştırılmalarına karşın emeklerinin karşılığını alamadıkları ifade edilir. Bunun yanında işçiler arasında acımasız bir rekabet ortamının varlığından söz edilse de işçilerin en azından bir kısmının bu düzeni benimsediği ve bunu zihin dünyalarında anlamlandırdığı görülür. Çalışma hayatı içinde makineleşmenin işsizlik sorununu arttıracağı belirtilirken yine makineleşme gerçeğinin işverenler tarafından işçilere karşı bir tehdit unsuru olarak kullanıldığı fark edilir. Fabrikalarda sendikal faaliyetler engellenmeye çalışılırken işçilerin, temel insani ihtiyaçlarını giderme noktasında sıkıntı yaşadığı, kadının ise cinsel saldırı tehdidi altında bulunduğu gösterilir.

Latife Tekin, Manves City'de bireysel çıkar ve heveslerin toplumun başat unsuru olmaya başladığını bunun da bireyler arasında güven bunalımını tetiklediğini sergiler. Bunun yanında bir başkasının davranışında art niyet arayan insan zihninin ahlak dışı durumlarla mücadele ederken ahlakdışı davranışın faili olduğu fark edilir. Ayrıca romanda adalet duygusunun gücünü yitirmesi ile yardımlaşmanın yerini güçlünün güçsüzü ezdiği bir düzene biraktığı belirtilir.

Manves City'de farklı ülkelerden Türkiye'ye göç etmiş insanlara ve bunların bir kısmının da suça karışmış olduğuna değinilir. Yazar, toplumda işlenen her suçun altında bu göçmenlerin olduğu önyargısını da dile getirir. Bununla birlikte göç olgusunun aile içi ilişkileri dahi etkilediği vurgulanır. Latife Tekin, kadın bağlamında bir erkeğin himayesine girmeden kadının ayakları üzerinde durmasının güçlügünü belirtir. Romanda altı çizilen bir unsur da kadına yönelik erkek şiddetidir. Bu noktada yazar, kadınların bu yazgıyı sonraki kuşak kadınlara aktardığını, erkeğin de bu olumsuz davranışı bir önceki kuşak erkeklerden devraldığını gösterir.

Manves City'de şehirleşme bağlamında çok hızlı bir değişimin varlığına değinilir. Bu şehirleşmenin sonuçlarından biri ise suç oranlarındaki artıştır ki toplumsal huzurun yitirilmesi de bu bağlamda değerlendirebilir. Yazar, çalıştırılacak sahipsiz ve yoksul insanların çok olmasını bir yerleşim yerinin sanayileşmesinin nedenleri içinde belirtir. Bu sanayileşmenin bir sonucu da tabiatın tahrip edilmesi ve tarım arazilerinin azalmasıdır. Bu bağlamda romanda yansıtılan bir sorun da plansız sanayileşmeye direnen toprak sahiplerinin zor kullanılarak devre dışı bırakılması ile ilgilidir.

\section{KAYNAKLAR}

Atik, Ş. (2011). Latife Tekin'in Romanlarında Yapı, Tema ve Anlatım (Yayımlanmamış doktora tezi). Gazi Üniversitesi/Sosyal Bilimler Enstitüsü.

Ayverdi: (1976). Millî Kültür Mes'eleleri ve Maârif Dâvâmız. Milli Eğitim.

Bal, H. (2008). Kent Sosyolojisi. Fakülte. 
Balık, M. (2011). Latife Tekin’’n Romancılı̆̆ı (Yayımlanmamış doktora tezi). Ankara Üniversitesi/Sosyal Bilimler Enstitüsü.

Başaran, E. (2014). Ailenin İşleyişi ya da Gerçekleştirimi. Mustafa Aydın (ed.), Sistematik Aile Sosyolojisi (2. Baskı) içinde (s. 141- 158). Çizgi.

Çakmaklı, K. (2009). Aile İçi İletişim ve Sosyal Sağlık (5. Baskı). Cilt 3. Nobel Tıp.

Frank, M., Roehrig, P. \& Pring, B. (2019). Makineler Her Şeyi Yaptı̆̆ında Biz Ne Yapacă̆ız. Emine Yılmaz (çev.). Aganta.

Keleş, R. (2002). Kentleşme Politikası (7. Baskı). İmge.

Kovel, J. (2005). Doğanın Düşmanı - Kapitalizmin Sonu Mu, Dünyanın Sonu Mu? Gürol Koca (Çev.). İstanbul: Metis.

Kurtkan, Â. (1977). Türk Milletinin Mânevi Değgerleri. Milli Eğitim.

Özgüven, İ.E. (2001). Ailede İletişim ve Yaşam. PDREM.

Tarhan, N. (2009). Makul Çözüm (11. Baskı). Timaş.

TDK, (2011), Türkçe Sözlük (11. Bask1). Türk Dil Kurumu.

Tekin, L. (2019). Manves City (2. Bask1). Can.

Türkdoğan, O. (1996). Değişme Kültür ve Sosyal Çözülme (2. Baskı). Birleşik.

Yıldız, Z., Zengin, N. \& Karagöz, Y. (2018). Yapısal Eşitlik Modellemesi ile Sendika Memnuniyeti Ölçeğinin Geliştirilmesi: Sivas İli Örneği. Türkiye Bilimsel Araştırmalar Dergisi, 1(3),93-102. http://tübad.com/Makaleler/84032544_7.\%20zafer\%20yıldız.pdf. 